\title{
Hydrogen Generation Scoping Study of Surrogate WSB Concrete Waste Forms
}

\author{
J. M. Duffey and R. R. Livingston
}

August 2003

\section{Westinghouse Savannah River Company \\ Savannah River Site \\ Aiken, SC 29808}

Prepared for the U. S. Department of Energy under Contract DE-AC09-96SR18500 
This document was prepared in conjunction with work accomplished under Contract No. DE-AC09-96SR18500 with the U. S. Department of Energy.

\section{DISCLAIMER}

This report was prepared as an account of work sponsored by an agency of the United States Government. Neither the United States Government nor any agency thereof, nor any of their employees, makes any warranty, express or implied, or assumes any legal liability or responsibility for the accuracy, completeness, or usefulness of any information, apparatus, product or process disclosed, or represents that its use would not infringe privately owned rights. Reference herein to any specific commercial product, process or service by trade name, trademark, manufacturer, or otherwise does not necessarily constitute or imply its endorsement, recommendation, or favoring by the United States Government or any agency thereof. The views and opinions of authors expressed herein do not necessarily state or reflect those of the United States Government or any agency thereof.

This report has been reproduced directly from the best available copy.

Available for sale to the public, in paper, from: U.S. Department of Commerce, National Technical Information Service, 5285 Port Royal Road, Springfield, VA 22161, phone: (800) 553-6847, fax: (703) 605-6900

email: orders@ntis.fedworld.gov

online ordering: http://www.ntis.gov/help/index.asp

Available electronically at http://www.osti.gov/bridge

Available for a processing fee to U.S. Department of Energy and its contractors, in paper, from: U.S. Department of Energy, Office of Scientific and Technical Information, P.O. Box 62, Oak Ridge, TN 37831-0062,

phone: (865)576-8401,

fax: (865)576-5728

email: $\underline{\text { reports@ adonis.osti.gov }}$ 
WSRC-TR-2003-00350

Revision 0

\title{
Hydrogen Generation Scoping Study of Surrogate WSB Concrete Waste Forms
}

\author{
J. M. Duffey and R. R. Livingston \\ Westinghouse Savannah River Company \\ Savannah River Site \\ Aiken, SC 29808
}

\subsection{Introduction}

The Department of Energy (DOE) plans to build a Waste Solidification Building (WSB) at the Savannah River Site (SRS) in South Carolina. The project is currently in the preliminary design phase. The WSB will produce a concrete waste form product from liquid waste streams received from the Pit Disassembly and Conversion Facility (PDCF) and the Mixed Oxide (MOX) Fuel Fabrication Facility (MFFF), which will be located at the SRS. The concrete waste form produced from one waste stream, referred to as the MOX high alpha waste stream, will be high in americium content. That waste form will be packaged in standard waste boxes (SWBs) for transport to the Waste Isolation Pilot Plant (WIPP) in the Transuranic Package Transporter-II (TRUPACT-II).

Due to the need to transport concrete waste forms with a higher wattage than is currently supported by the existing analytical methods defined in the TRUPACT-II Authorized Methods for Payload Control (TRAMPAC), ${ }^{1}$ gas generation testing is needed to determine acceptable levels of moisture content for the waste form. Radiolytic hydrogen is produced by the interaction of ionizing radiation with hydrogenous materials (including water). ${ }^{2}$ In studies with radioactive concrete waste forms at the SRS it was demonstrated that hydrogen generation increases with increasing moisture content of the waste form. ${ }^{3}$ The purpose of this scoping study was to evaluate the potential for hydrogen generation from cement waste forms similar in composition to those to be produced in the WSB. ${ }^{4}$ The goal of these scoping tests was to demonstrate that a concrete waste form with limited moisture content and high americium loading (i.e., >240 g americium-241 per SWB) will meet hydrogen generation requirements for shipment to the WIPP.

In this scoping study surrogate radioactive concrete waste forms were prepared at water-to-cement mass ratios (w/c) of 0.2 and 0.3 and sealed in pressure vessels. Pressure and temperature were recorded electronically for the duration of the test. After about 11 days, the headspace gas of each vessel was sampled and analyzed by gas chromatography for hydrogen, oxygen, and nitrogen content. The data collected during these tests were used to estimate hydrogen gas generation rates and hydrogen G-values (molecules of hydrogen produced per $100 \mathrm{eV}$ radioactive decay energy deposited) for waste forms prepared at each w/c ratio.

\subsection{Background}

Of the waste streams to be received and treated in the WSB, only the MOX high alpha waste stream is intended for the WIPP. Consequently, it is the only stream of interest in this scoping study. The high alpha waste stream will contain the following maximum quantities of constituents per year: silver (449 kg); sodium (147 kg); gallium (42 $\mathrm{kg}$ ); americium-241 (24 kg); plutonium-239 (221 g); uranium-235 (< $13 \mathrm{~g})$; various nitrate salts (1200 kg); organics $(<25 \mathrm{~kg})$; and trace quantities of lead, thallium, and mercury. The total volume of the waste stream will be about $84,000 \mathrm{~L}$ per year, and the acidity will range from $3.1 \mathrm{M}$ nitric acid to $4.8 \mathrm{M}$ nitric acid. ${ }^{5}$ Upon receipt by the WSB, the high alpha waste stream will be concentrated by evaporation, neutralized to $1.0 \mathrm{M}$ free hydroxide, and solidified by cementing into a concrete waste form. The concrete waste form will be containerized in a SWB. Each SWB will 
contain about $1300 \mathrm{~kg}$ of concrete waste form, including an average of $164 \mathrm{~g}$ americium-241 (18.5 W) and a maximum of $247 \mathrm{~g}$ americium-241 (27.9 W).

To achieve the desired americium loading in the concrete waste form, the hydrogen G-value $\left(\mathrm{G}_{\mathrm{H} 2}\right)$ for the waste form must be lower than the bounding $\mathrm{G}_{\mathrm{H} 2}$ of 0.4 currently published in the TRAMPAC. The actual $\mathrm{G}_{\mathrm{H} 2}$ required will depend on the packaging configuration (e.g., number of filter vents, layers of confinement, free volume). The maximum allowable wattage per SWB can be calculated from the following equations taken from Appendix 5.5 of the TRAMPAC: ${ }^{6}$

$$
\begin{gathered}
Q_{i}=\frac{X_{\text {inner }} * N_{A} * 1.602 \mathrm{E}-19 \mathrm{~W} \cdot \mathrm{s} / \mathrm{eV}}{R_{T} * G_{H_{2}} / 100 \mathrm{eV}} \\
\text { or } \\
Q_{i}=\frac{4824.42 \mathrm{molecules} / \mathrm{mole} * \mathrm{~W} \cdot \mathrm{s} / \mathrm{eV}}{(Z Z Z Z * Y Y Y Y) \mathrm{s} \cdot \mathrm{molecules} / \mathrm{mole} \cdot \mathrm{eV}}
\end{gathered}
$$

where:

$Q_{i} \quad=\quad$ decay heat limit (wattage) per generator, in this case per SWB (W),

$X_{\text {inner }}=$ mole fraction of hydrogen in innermost layer $=0.05$ (maximum permissible concentration),

$N_{A}=$ Avogadro's number $=6.023 \mathrm{E}+23$ molecules $/ \mathrm{mole}$,

$R_{T} \quad=$ the total resistance to the release of hydrogen from the innermost layer (s/mol),

$Z Z Z Z=$ numeric shipping category notation for the total resistance factor $=R_{T}$ divided by 10,000 , and

$Y Y Y Y=$ numeric shipping category notation for $\mathrm{G}_{\mathrm{H} 2}$ for the waste material type $=\mathrm{G}_{\mathrm{H} 2}$ multiplied by 100 .

For a SWB with two filter vents and no additional layers of confinement, the total resistance factor ZZZZ was determined to be $0024\left(R_{T}=240,000\right)$ using Table 5.4-1, Numeric Payload Shipping Category Worksheet, from Appendix 5.5 of the TRAMPAC. ${ }^{\mathrm{i}}$ For a $\mathrm{G}_{\mathrm{H} 2}$ of 0.4 (bounding value for solidified aqueous inorganic concreted waste), $Y Y Y Y$ equals 0040 and the decay heat limit per SWB is

$$
Q_{i}=\frac{4824.42 \text { molecules } / \text { mole } * \mathrm{~W} \cdot \mathrm{s} / \mathrm{eV}}{(0024 * 0040) \mathrm{s} \cdot \text { molecules } / \mathrm{mole} \cdot \mathrm{eV}}=5.0 \mathrm{~W}
$$

By rearranging equation 2 to solve for $Y Y Y Y$ (or $\mathrm{G}_{\mathrm{H} 2} * 100$ ), it is possible to calculate the $\mathrm{G}_{\mathrm{H} 2}$ needed to achieve a given decay heat limit (i.e., americium loading) for this same packaging configuration. Therefore, to achieve a maximum americium loading of $247 \mathrm{~g}(28 \mathrm{~W})$ per SWB would require $\mathrm{a}_{\mathrm{H} 2}$ of 0.072 or less. ${ }^{\text {ii }}$

One way to achieve such a low $\mathrm{G}_{\mathrm{H} 2}$ for a concrete waste form is to limit its water content. Bibler measured a $\mathrm{G}_{\mathrm{H} 2}$ of 0.38 for a Portland concrete waste form spiked with plutonium-238 at a water content of $35 \mathrm{wt} \%{ }^{3}$ Upon heating to reduce the water content, the $\mathrm{G}_{\mathrm{H} 2}$ decreased to 0.20 at $28 \mathrm{wt} \%$ water and to 0.0002 at $7.4 \mathrm{wt} \%$ water. Similar reductions in $\mathrm{G}_{\mathrm{H} 2}$ were achieved by pressing the concrete to remove water. The presence of nitrate or nitrite ions at concentrations of $6 \mathrm{M}$ or $5 \mathrm{M}$, respectively, in the water used to make the concrete also reduced the observed $\mathrm{G}_{\mathrm{H} 2}$ by about a factor of ten.

${ }^{\mathrm{i}}$ During completion of this worksheet we assumed (1) a confinement layer equivalent to a rigid drum liner with a 2" diameter hole (total resistance factor $=5$ ), (2) a direct-loaded SWB payload container with two filters having a minimum hydrogen diffusivity of 7.4E- $06 \mathrm{~mol} / \mathrm{s} / \mathrm{mol}$ fraction (total resistance factor $=937$ for 2 filters), and a direct-loaded SWB load type (total resistance factor $=1430$ ). The sum of all the total resistance factors divided by 100 and rounded up to the nearest whole number gives $Z Z Z Z=(5+937+1430) / 100=0024$.

ii The actual $\mathrm{G}_{\mathrm{H} 2}$ required to achieve a decay heat limit of $28 \mathrm{~W}$ may be more or less than 0.072 depending on the actual filter hydrogen diffusivity and the number of filters used in the SWB. 
The approach favored by the WSB engineering team was to limit the amount of water used to prepare the concrete waste form with the goal of minimizing $\mathrm{G}_{\mathrm{H} 2}$. To this end, it was decided that the radioactive surrogate waste forms for these scoping tests be prepared at w/c ratios of 0.2 (14.5 wt $\%$ water) and $0.3(19.2 \mathrm{wt} \%$ water). It was also recognized that the high nitrate concentration of the neutralized waste solution might further reduce the observed $\mathrm{G}_{\mathrm{H} 2}$ for the concrete waste forms.

\subsection{Experimental}

\subsection{Preparation of Radioactive Surrogate Waste Forms}

Radioactive surrogate concrete waste forms for gas generation testing were prepared based on discussions with the Waste Processing Technology Section (WPT) of the Savannah River Technology Center and WSB engineering personnel and on specifications for MOX high alpha waste provided in the WSB flow sheet. An acidic evaporator bottoms simulant solution was prepared by WPT and provided to SRTC Actinide Technology Section (ATS) personnel for the preparation of concrete waste forms. This simulant solution provided by WPT consisted of average constituent concentrations minus radioactive, RCRA (Resource Conservation and Recovery Act) regulated, and organic components. Table 1 lists the simulant solution ingredients and concentrations.

Table 1. Recipe for $250 \mathrm{~mL}$ Acidic Evaporator Bottoms Simulant ${ }^{\text {iii }}$

\begin{tabular}{|l|r|}
\hline Constituent & Grams per $250 \mathrm{~mL}$ \\
\hline $\mathrm{Ce}\left(\mathrm{NO}_{3}\right)_{3} \bullet 6 \mathrm{H}_{2} \mathrm{O}$ & 0.121 \\
\hline $\mathrm{HNO}_{3}(68 \%)$ & 127.820 \\
\hline $\mathrm{Ga}\left(\mathrm{NO}_{3}\right)_{3}$ & 1.913 \\
\hline $\mathrm{NaNO}$ & 6.652 \\
\hline $\mathrm{Ca}\left(\mathrm{NO}_{3}\right)_{2}$ & 21.194 \\
\hline $\mathrm{KNO}_{3}$ & 24.562 \\
\hline $\mathrm{Mg}\left(\mathrm{NO}_{3}\right)_{2} \bullet 6 \mathrm{H}_{2} \mathrm{O}$ & 31.904 \\
\hline
\end{tabular}

Table 2 gives the range of expected concentrations for the predominant alpha-emitting constituents in the concrete waste form and the corresponding maximum alpha activity per gram of waste form.

Table 2. Alpha-Emitting Constituents of MOX High Alpha Cement Waste Form ${ }^{\text {iv }}$

\begin{tabular}{|c|c|c|c|c|c|c|}
\hline Constituent & $\begin{array}{c}\text { Minimum } \\
\text { Conc. }\end{array}$ & $\begin{array}{c}\text { Average } \\
\text { Conc. }\end{array}$ & $\begin{array}{c}\text { Maximum } \\
\text { Conc. }\end{array}$ & $\begin{array}{c}\text { Isotope } \\
\text { Specific } \\
\text { Activity }\end{array}$ & $\begin{array}{c}\text { Maximum } \\
\text { Waste Form } \\
\text { Activity }\end{array}$ & $\begin{array}{c}\text { Maximum } \\
\text { Waste Form } \\
\text { Activity }\end{array}$ \\
\hline & $(\mathrm{wt} \%)$ & $(\mathrm{wt} \%)$ & $(\mathrm{wt} \%)$ & $(\mathrm{Bq} / \mathrm{g})$ & $(\mathrm{Bq} / \mathrm{g})$ & $(\%)$ \\
\hline $\mathrm{Am}-241$ & $1.24 \mathrm{E}-02$ & $1.27 \mathrm{E}-02$ & $1.90 \mathrm{E}-02$ & $1.27 \mathrm{E}+11$ & $2.41 \mathrm{E}+07$ & 99.96 \\
\hline $\mathrm{Pu}-239$ & $1.14 \mathrm{E}-04$ & $1.14 \mathrm{E}-04$ & $4.58 \mathrm{E}-04$ & $2.27 \mathrm{E}+09$ & $1.04 \mathrm{E}+04$ & 0.04 \\
\hline $\mathrm{U}-235$ & $3.22 \mathrm{E}-03$ & $3.22 \mathrm{E}-03$ & $1.29 \mathrm{E}-02$ & $7.93 \mathrm{E}+04$ & $1.02 \mathrm{E}+01$ & 0.00 \\
\hline
\end{tabular}

\footnotetext{
iii Simulant recipe provided by WPT personnel.

${ }^{\text {iv }}$ Concentration ranges provided by WSB engineering.
} 
As seen from Table 1, americium-241 is expected to account for greater than $99.9 \%$ of the total alpha activity in the cement waste form. Because sufficient americium was not available for these scoping tests, the surrogate waste forms were spiked with plutonium-238 instead. ${ }^{\mathrm{V}}$ Plutonium-238 was considered a good surrogate for americium-241 because (1) their alpha particle energies are very similar and (2) the desired amount of activity could be added without adding too much plutonium mass to the waste form. Enough plutonium-238 was used to provide an alpha activity equivalent to approximately two times the maximum activity from Table 1 (i.e., 2.4E+07 Bq per $\mathrm{g}$ of cement waste form) to accelerate the screening tests.

Spiked surrogate waste forms were prepared in an ATS radioactive glovebox historically used for plutonium-238 work. The desired amount of plutonium-238 was added to the acidic surrogate solution provided by WPT from a stock solution that was nominally $0.39 \mathrm{~g} / \mathrm{L}$ plutonium- 238 in $5 \mathrm{M}$ nitric acid. ${ }^{\text {vi }}$ Plutonium- 238 was added at this stage to ensure mixing with the other waste constituents in a manner similar to that expected for the actual waste. This solution was neutralized to nominally $1.0-\mathrm{M}$ free hydroxide with $50 \%$ sodium hydroxide solution. The neutralized slurry was then combined with sufficient cement to obtain water-to-cement ratios of either 0.2 or 0.3 . The cement used in these tests was Type I portland cement (as defined by ASTM Standard C 150-02a) obtained from the Saltstone Facility in Z-Area. ${ }^{7}$ Duplicate samples were prepared at each w/c ratio and the samples were cast into 20 -mL stainless steel insert that could subsequently be placed into the sample container for testing. Several holes were made in each sample to allow for insertion of the thermocouple and to provide pathways for gas to escape the waste form. The samples were covered with metal foil and a plastic cap and packaged for removal from the glovebox.

\subsection{Gas Generation Tests}

The surrogate radioactive waste forms were transferred from the plutonium-238 glovebox in which they were prepared and placed into another ATS radioactive glovebox for gas generation testing within 24 hours. The filled sample inserts were placed into stainless steel test vessels (Figure 1) and sealed in air at atmospheric pressure to initiate the tests. A blank consisting of an empty insert in an identical test vessel was also sealed in air and monitored along with the test samples. Each test vessel was equipped with a Sensotec pressure transducer (0 to 100 psia; minimum accuracy $\pm 0.1 \%$ full scale, or $\pm 0.1 \mathrm{psi}$ (5.2 Torr)) and type-J thermocouple. The thermocouple extended part way down into the cement sample. The sealing surfaces used in constructing these test vessels consisted of both a flange fitting and a metal face-seal fitting. Helium leak testing was previously performed on these containers as part of a different research program. At that time the sample containers were all shown to leak at a rate of less than $1.0 \mathrm{E}-08$ standard cubic centimeters per second. Pressure and temperature of the sealed systems were monitored and logged electronically at regular intervals using Labview data acquisition software.

To account for pressure changes not due to radiolysis, two non-radioactive concrete samples (w/c ratios of 0.2 and 0.3 ) were prepared in the same manner as the radioactive samples and placed in the test program approximately two days later. These sample test vessels were maintained in the same laboratory module but outside the glovebox. Their pressure and temperature data were logged electronically using the same Labview software.

\footnotetext{
v The plutonium-238 solution used in these experiments contained nominally $83 \mathrm{wt} \%$ plutonium-238 which accounted for $>99.8 \%$ of the total alpha activity.

${ }^{\text {vi }}$ Based on analysis of this stock solution by liquid scintillation, the $\mathrm{Pu}-238$ concentration may have been as high as $0.56 \mathrm{~g} / \mathrm{L}$ ( $\sim 44 \%$ higher). However, the nominal value of $0.39 \mathrm{~g} / \mathrm{L}$ was used to calculate the plutonium loading of the concrete waste forms and $\mathrm{G}_{\mathrm{H} 2}$ because the resulting $\mathrm{G}$-values are more conservative.
} 
WSRC-TR-2003-00350

Revision 0

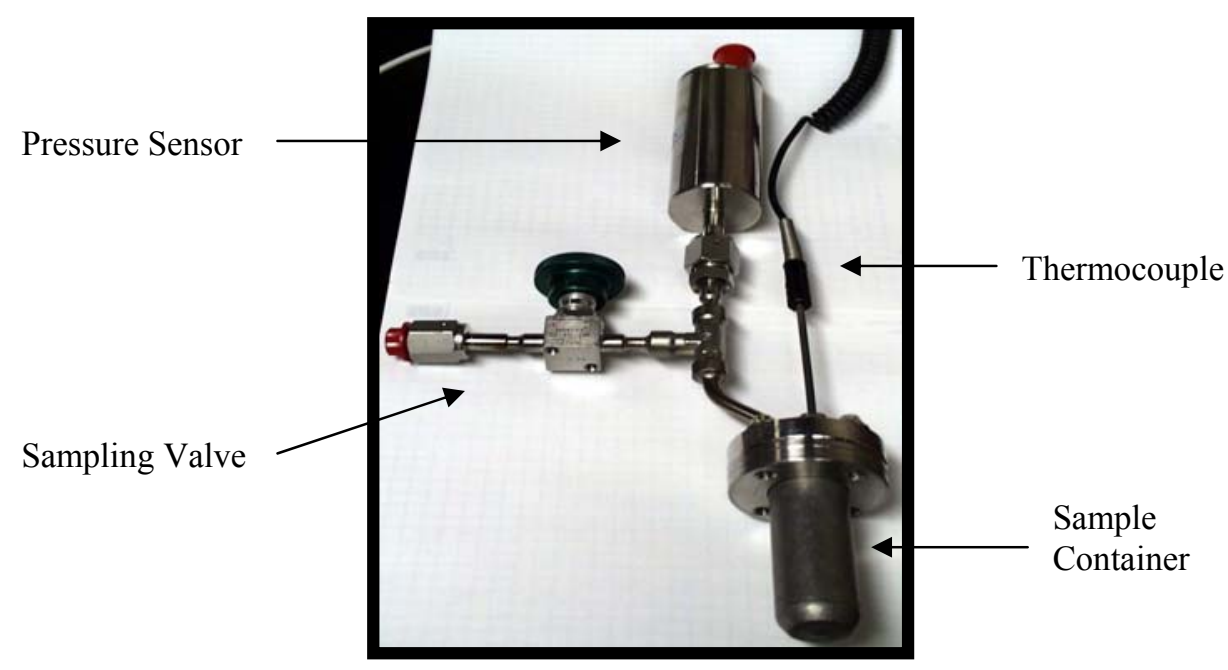

Figure 1. Stainless steel test vessel with associated pressure transducer, thermocouple and sampling valve.

\subsection{Headspace Gas Analysis}

At the conclusion of the tests, the headspace gas of each test vessel was sampled and analyzed by gas chromatography. To ensure enough gas was collected for analysis, argon was added to the headspace of each test vessel to a total pressure of approximately 4500 Torr and allowed to equilibrate overnight prior to sampling. Average hydrogen gas generation rates and hydrogen G-values were calculated from the amount of hydrogen produced over the duration of the tests and the total alpha decay energy by assuming that all of the decay energy was deposited in the samples.

\subsection{Results and Discussion}

\subsection{Pressure Change Over Time}

Figure 2 is a plot of pressure and temperature over time for the four radioactive test samples and the blank (vessel with empty insert). All five samples were located in a stainless steel rack in the radioactive glovebox. Samples 0.2a and $0.2 \mathrm{~b}$ had $\mathrm{a} \mathrm{w} / \mathrm{c} 0.2$ and samples $0.3 \mathrm{a}$ and $0.3 \mathrm{~b}$ had a w/c of 0.3 . With the exception of sample $0.3 \mathrm{~b}$ (black trace), changes in temperature were accompanied by corresponding changes in pressure in each of the test vessels, as expected for sealed vessels containing constant or nearly constant amounts of gas. The relative lack of correspondence between temperature and pressure changes seen for the pressure trace of sample $0.3 \mathrm{~b}$ (black) compared to the temperature traces is often indicative of a leaking vessel. When attempting to sample the headspace gas for analysis, this test vessel was found to leak through the sampling valve. Because of this leak, we were unable to collect a representative sample of the headspace gas for sample $0.3 \mathrm{~b}$, so no gas composition data were obtained for this sample. 
WSRC-TR-2003-00350

Revision 0

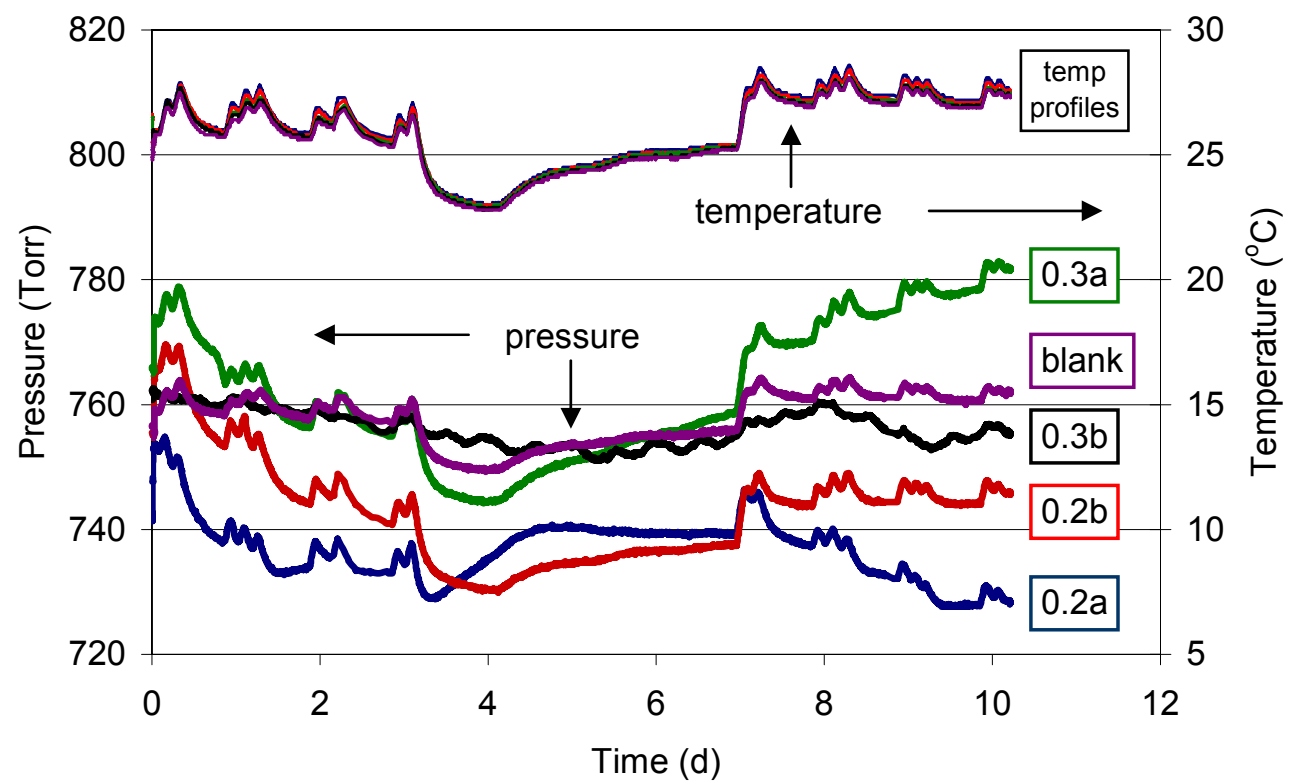

Figure 2. Plot of pressure and temperature over time for samples $0.2 \mathrm{a}$ (blue), $0.2 \mathrm{~b}$ (red), $0.3 \mathrm{a}$ (green), $0.3 \mathrm{~b}$ (black) and blank (purple). Samples 0.2a and 0.2b have a w/c of 0.2. Samples 0.3a and $0.3 b$ have a w/c of 0.3. The blank is an empty sample container.

The relatively large changes in temperature during these tests complicate the interpretation of the observed changes in pressure. Therefore, to discern changes in pressure due to gas generation (or consumption), the pressure data were corrected to a constant temperature of $25{ }^{\circ} \mathrm{C}$ according to equation 4 ,

$$
P t c=P /(273+T) \times 298
$$

where:

Ptc $=$ sample container pressure corrected to $298 \mathrm{~K}$,

$P \quad=\quad$ sample container pressure at temperature $T\left(\right.$ in ${ }^{\circ} \mathrm{C}$ ),

$T=$ temperature inside sample container.

Figure 3 is a plot of pressure $\left(\right.$ at $25^{\circ} \mathrm{C}$ ) over time for three of the four radioactive test samples ( $3 \mathrm{~b}$ not shown), the blank, and the two non-radioactive control samples ( 0.2 control and 0.3 control). The blank (purple trace) showed little or no change in pressure during the test and this test container was not sampled. However, both non-radioactive control sample containers decreased in pressure, which points to a non-radiolytic mechanism of reaction causing this pressure decrease. The radioactive sample containers also experienced an initial decrease in pressure much like the control samples. However, sample containers $0.2 \mathrm{~b}$ and $0.3 \mathrm{a}$ began to increase in pressure after about four days, with the rate of pressure increase being greater for the sample containing more water (i.e., $0.3 \mathrm{a}$ ). The pressure changes in sample container $0.2 \mathrm{a}$ were much more erratic than for either $0.2 \mathrm{~b}$ or $0.3 \mathrm{a}$. 
WSRC-TR-2003-00350

Revision 0

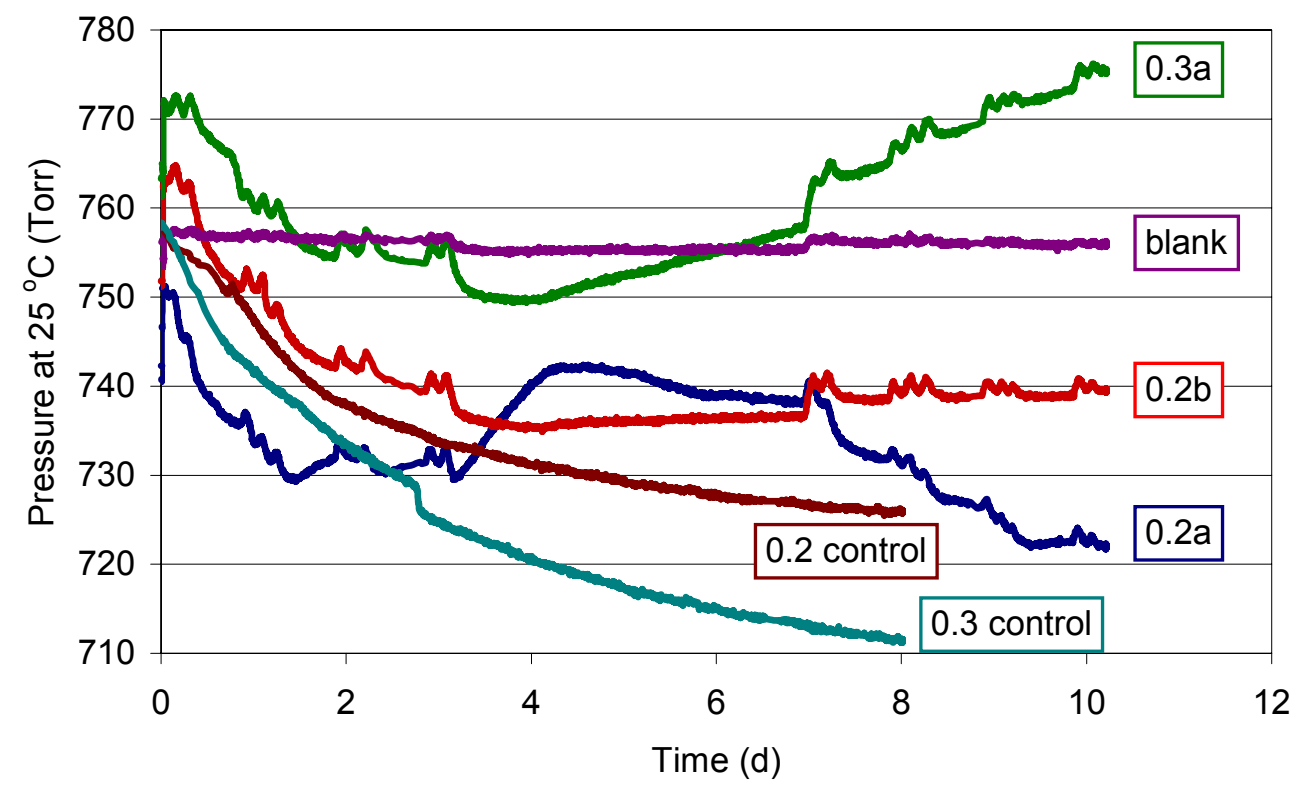

Figure 3. Plot of pressure corrected to $25{ }^{\circ} \mathrm{C}$ over time for samples $0.2 \mathrm{a}$ (dark blue), $0.2 \mathrm{~b}$ (red), $0.3 \mathrm{a}$ (dark green), blank (purple), 0.2 control (brown) and 0.3 control (light blue/green). Samples $0.2 \mathrm{a}, 0.2 \mathrm{~b}$, and 0.2 control have a w/c of 0.2 . Samples $0.3 \mathrm{a}, 0.3 \mathrm{~b}$, and 0.3 control have a $\mathrm{w} / \mathrm{c}$ of 0.3 . The blank is an empty sample container.

\subsection{Headspace Gas Analysis}

The results of the headspace gas analyses are presented in Table 3. Sample $0.3 \mathrm{~b}$ was lost due to the leaking valve and the blank was not sampled because there was little or no change in the container pressure during the test. All three of the remaining radioactive samples generated some hydrogen and a trace amount of hydrogen was found in the control samples. Sample container 0.3a, the sample with the highest water content, had the greatest hydrogen concentration at the end of the test.

The nitrogen-to-oxygen ratio in each of the sample containers was calculated for comparison with that of air. Dry air contains $78.08 \%$ nitrogen and $20.95 \%$ oxygen, or a nitrogen-to-oxygen ratio of 3.73 . Both control samples had an increased nitrogen-to-oxygen ratio indicating that the observed pressure decrease was due to a net consumption of oxygen. Bibler also reported a pressure decrease over both radioactive and nonradioactive concrete samples after heating to $200{ }^{\circ} \mathrm{C}$ to reduce the water content. ${ }^{3}$ Consumption of oxygen may be due to oxidizable metal impurities in the cement premix (e.g., iron metal and/or iron(II) ions). ${ }^{8}$ This hypothesis is supported by observed pressure decreases over nonradioactive concrete samples prepared from only water and cement $(\mathrm{w} / \mathrm{c}=0.3)$ and subsequently sealed in air (see Figure 4). The nitrogen-to-oxygen ratios for the radioactive samples were similar to the ratio for dry air (i.e., 3.73). This observation combined with the observed oxygen consumption for the non-radioactive control samples suggests that radiolytic oxygen was being produced in the radioactive samples. This is not unexpected because Bibler reported both hydrogen and oxygen generation for alpha-irradiation of concrete samples. $^{3}$ 
WSRC-TR-2003-00350

Revision 0

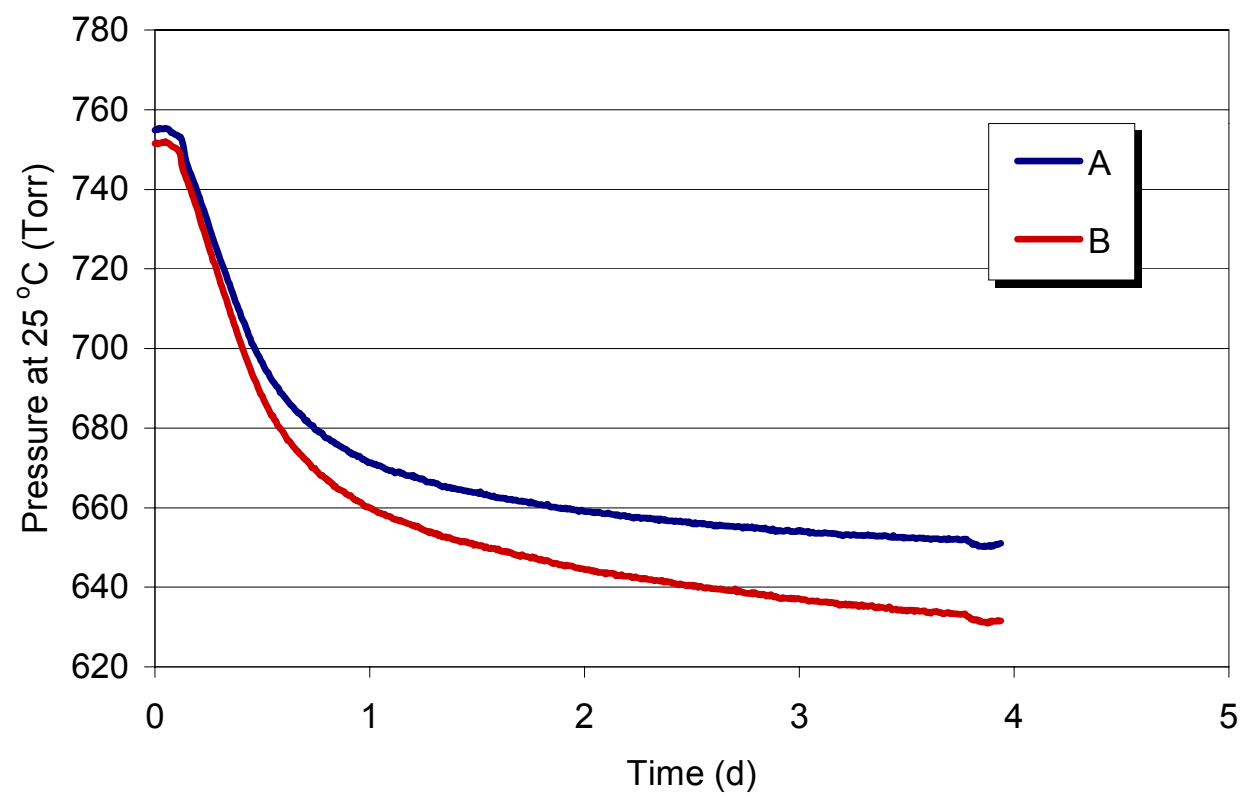

Figure 4. Plot of pressure over time for nonradioactive concrete samples prepared from only water and cement (w/c of 0.3) and sealed in air. Samples A and B are duplicates but the sample mass-to-headspace volume ratios are not identical.

Table 3. Headspace Gas Analyses Results

\begin{tabular}{|l|c|c|c|c|}
\hline \multicolumn{1}{|c|}{ Sample } & $\mathbf{\% H}_{\mathbf{2}}{ }^{\mathbf{a}}$ & $\mathbf{\% N}_{\mathbf{2}}$ & $\mathbf{\% O}_{\mathbf{2}}$ & $\mathbf{N}_{\mathbf{2}}: \mathbf{O}_{\mathbf{2}}$ Ratio \\
\hline $0.2 \mathrm{a}$ & $0.091 \pm 0.01^{\mathrm{c}}$ & $80 \pm 3$ & $21.5 \pm 0.8$ & $3.7 \pm 0.2$ \\
\hline $0.2 \mathrm{~b}$ & $0.51 \pm 0.01$ & $79 \pm 1$ & $19.9 \pm 0.3$ & $4.0 \pm 0.1$ \\
\hline $0.3 \mathrm{a}$ & $1.11 \pm 0.03$ & $72 \pm 3$ & $19.8 \pm 0.7$ & $3.6 \pm 0.2$ \\
\hline $0.3 \mathrm{~b}$ & Not Measured & Not Measured & Not Measured & Not Measured \\
\hline 0.2 control & $0.023 \pm 0.002$ & $84 \pm 1$ & $19.0 \pm 0.3$ & $4.4 \pm 0.1$ \\
\hline 0.3 control & $0.031 \pm 0.004$ & $78 \pm 2$ & $17.5 \pm 0.7$ & $4.4 \pm 0.2$ \\
\hline Blank & Not Measured & Not Measured & Not Measured & Not Measured \\
\hline
\end{tabular}

${ }^{a}$ The limit of detection for hydrogen in these analyses was approximately $0.003 \%$.

${ }^{\mathrm{b}}$ For dry air the nitrogen-to-oxygen ratio is 3.73 .

${ }^{\mathrm{c}}$ Reported uncertainties are one standard deviation of the average of three or four gas chromatograph measurements. 
WSRC-TR-2003-00350

Revision 0

\subsection{Hydrogen Generation Rates and G-values}

Hydrogen gas generation rates and hydrogen G-values were calculated from the experimental data as follows:

$$
\text { rate }=\frac{n_{H_{2}}}{t \cdot m}
$$

and

where:

$$
G_{H_{2}}=\frac{n_{H_{2}} \cdot A}{t \cdot m \cdot \frac{P}{100}}
$$

rate $=$ moles of hydrogen generated per second per kilogram of concrete waste form,

$n_{H 2}=$ moles of hydrogen produced,

$t=$ test duration in seconds,

$m=$ mass of concrete waste form in kilograms,

$G_{H 2}=$ hydrogen G-value, molecules of hydrogen produced per $100 \mathrm{eV}$ of radioactive decay energy absorbed (assumed $100 \%$ of the decay energy was absorbed by the sample),

$A=$ Avogadro's number, $6.022 \times 10^{23}$,

$P \quad=\quad$ specific power of concrete waste form in $\mathrm{eV} / \mathrm{s} / \mathrm{kg}$.

The number of moles of hydrogen produced $\left(n_{H 2}\right)$ was calculated according to equation 7 ,

where:

$$
n_{H_{2}}=\frac{c_{H_{2}} \cdot p \cdot V}{R \cdot T}
$$

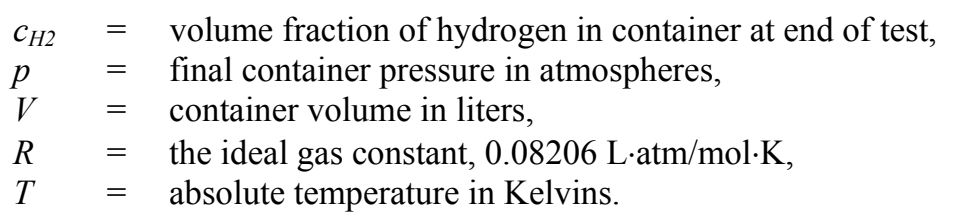

Table 4 gives the hydrogen generation rate and $\mathrm{G}_{\mathrm{H} 2}$ measured for the surrogate concrete waste forms, along with pertinent experimental quantities. The fastest hydrogen generation rate and largest $\mathrm{G}_{\mathrm{H} 2}$ were measured for sample $0.3 \mathrm{a}$, with a w/c ratio of 0.3 . The measured $\mathrm{G}_{\mathrm{H} 2}$ of 0.037 is about a factor of two less than the estimated $\mathrm{G}_{\mathrm{H} 2}$ of 0.072 needed to achieve the desired americium loading of $28 \mathrm{~W}$ per SWB. $\mathrm{G}_{\mathrm{H} 2}$ values of 0.003 and 0.015 were observed for samples $0.2 \mathrm{a}$ and $0.2 \mathrm{~b}$, respectively. If one used the plutonium- 238 content based on liquid scintillation analysis of the stock solution, the measured $\mathrm{G}_{\mathrm{H} 2}$ values would be $0.026,0.002$ and 0.010 for samples $0.3 \mathrm{a}, 0.2 \mathrm{a}$ and $0.2 \mathrm{~b}$, respectively. The reason for the factor of five difference between $\mathrm{G}_{\mathrm{H} 2}$ for samples $0.2 \mathrm{a}$ and $0.2 \mathrm{~b}$ might be due to a small leak in container 0.2a that resulted in a slower buildup of hydrogen. This container was observed to leak slowly when the headspace gas was diluted with argon just prior to sampling. It is also possible, but less likely, that the release rate of hydrogen from the concrete was much lower for $0.2 \mathrm{a}$ than for $0.2 \mathrm{~b}$. At this time we have not run sufficient replicate experiments with concrete waste forms to define the reproducibility of the measured gas generation rates for these samples or reproducibility in sample preparation. 
WSRC-TR-2003-00350

Revision 0

Table 4. Gas Generation Rates and $\mathbf{G}_{\mathrm{H} 2}$ for Concrete Waste Forms

\begin{tabular}{|c|c|c|c|c|c|c|c|c|}
\hline Sample ID & $\begin{array}{c}\text { Sample } \\
\text { Wt }\end{array}$ & $\begin{array}{c}\text { w/c } \\
\text { Ratio }\end{array}$ & $\begin{array}{c}\text { Pu-238 } \\
\text { Loading }^{\mathrm{a}}\end{array}$ & $\begin{array}{l}\text { Specific } \\
\text { Power }^{a}\end{array}$ & $\begin{array}{c}\text { Headspace } \\
\text { Volume }\end{array}$ & $\begin{array}{c}\text { Test } \\
\text { Duration }\end{array}$ & $\begin{array}{c}\mathrm{H}_{2} \\
\text { Generation } \\
\text { Rate }\end{array}$ & $\mathbf{G}_{\mathrm{H} 2}{ }^{\mathrm{a}}$ \\
\hline & (g) & & (mg) & $(e V / s / g)$ & $(m L)$ & (d) & $(\mathrm{mol} / \mathrm{s} / \mathrm{kg})$ & \\
\hline $0.2 \mathrm{a}$ & 39.05 & 0.2 & 2.54 & $2.27 E+14$ & 10.6 & 11.19 & $9.93 \mathrm{E}-12$ & $0.003^{b}$ \\
\hline $0.2 b$ & 39.62 & 0.2 & 2.58 & 2.27E+14 & 10.4 & 11.18 & $5.52 \mathrm{E}-11$ & 0.015 \\
\hline $0.3 a$ & 33.62 & 0.3 & 2.71 & $2.81 \mathrm{E}+14$ & 12.1 & 11.19 & $1.72 \mathrm{E}-10$ & 0.037 \\
\hline $0.3 b$ & 29.79 & 0.3 & 2.40 & $2.81 \mathrm{E}+14$ & 14.0 & NA & $\begin{array}{c}\text { Not } \\
\text { Measured }\end{array}$ & $\begin{array}{c}\text { Not } \\
\text { Measured }\end{array}$ \\
\hline blank & 0.00 & NA & NA & $0.00 \mathrm{E}+00$ & 29.5 & NA & $\begin{array}{c}\text { Not } \\
\text { Measured }\end{array}$ & $\begin{array}{c}\text { Not } \\
\text { Measured }\end{array}$ \\
\hline 0.2 control & 39.18 & 0.2 & 0.2 & $0.00 \mathrm{E}+00$ & 10.6 & 9.04 & 1.93E-12 & NA \\
\hline 0.3 control & 41.39 & 0.3 & 0.3 & $0.00 \mathrm{E}+00$ & 9.2 & 9.06 & $2.13 \mathrm{E}-12$ & NA \\
\hline
\end{tabular}

${ }^{\mathrm{a}}$ Based on Pu-238 stock solution concentration of $0.39 \mathrm{~g} / \mathrm{L}$; specific power values based on analyzed Pu- 238 stock solution concentration value of $0.56 \mathrm{~g} / \mathrm{L}$ would be $\sim 44 \%$ higher and $\mathrm{G}_{\mathrm{H} 2}$ would be $\sim 30 \%$ lower. Therefore, the uncertainties in the measured $\mathrm{G}_{\mathrm{H} 2}$ values are dominated by the uncertainty in the specific power value and are estimated to be between $+10 \%$ and $-35 \%$ of the $\mathrm{G}_{\mathrm{H} 2}$ values listed in Table 4 .

${ }^{\mathrm{b}}$ A slow leak was observed in this sample container upon dilution of the headspace gas with argon just prior to sampling.

\subsection{Post-Sampling Observations}

After sampling the headspace gas of the test vessels, the vessels were resealed and we continued to record pressure and temperature inside the containers. Figure 5 is a plot of the temperature-corrected pressure traces for the radioactive samples before and after sampling. The pressures in sample containers $0.2 \mathrm{~b}$ (red trace) and $0.3 \mathrm{a}$ (green trace) after sampling have continued to increase at about the same rates that were observed prior to sampling (from about day four to day 10 of the study). After sampling, the pressure in sample container $0.2 \mathrm{a}$ (blue trace) has increased at about the same rate as that for sample $0.2 \mathrm{~b}$ (red trace), which suggests that container $0.2 \mathrm{a}$ probably was leaking during the first 10 days of the study. Sample container $0.3 \mathrm{~b}$ (yellow trace) appeared to continue leaking after sampling. After about 30 days, sample $0.3 \mathrm{~b}$ was moved to a different sample container which was not leaking. From that point on, the pressure over sample $0.3 \mathrm{~b}$ has increased steadily at a rate intermediate between that of sample container $0.3 \mathrm{a}$ (green trace) and containers $0.2 \mathrm{a}$ (blue trace) and $0.2 \mathrm{~b}$ (red trace). The pressure trends for the sets of duplicate samples are not expected to be identical because the sample weights and container volumes are not identical for each duplicate set (see Table 4 above). Nevertheless, the similar pressure trends observed for containers $0.2 \mathrm{~b}$ and $0.3 \mathrm{a}$ before and after gas sampling, and for the duplicate sample sets following sampling, provide additional confidence in the $\mathrm{G}_{\mathrm{H} 2}$ values reported for samples $0.2 \mathrm{~b}$ and $0.3 \mathrm{a}$ in Table 4. 
WSRC-TR-2003-00350

Revision 0

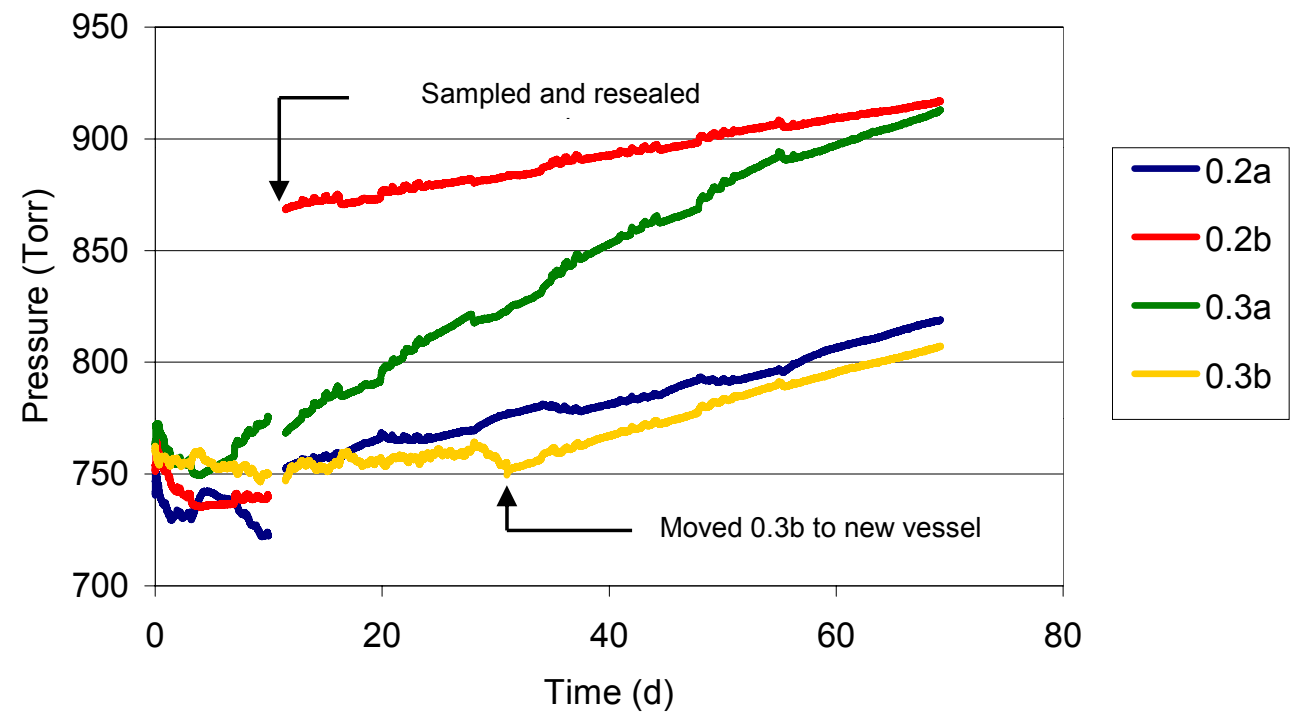

Figure 5. Plot of sample container pressure at $25{ }^{\circ} \mathrm{C}$ over time before and after sampling headspace gas. Samples $0.2 \mathrm{a}$ and $0.2 \mathrm{~b}$ have $w / \mathrm{c}$ of 0.2 . Samples $0.3 \mathrm{a}$ and $0.3 \mathrm{~b}$ have $\mathrm{w} / \mathrm{c}$ of 0.3 .

\subsection{Summary and Conclusions}

Hydrogen generation scoping tests were conducted with surrogate concrete waste forms spiked with plutonium-238 and prepared at water-to-cement ratios of 0.2 and 0.3 . The maximum observed $\mathrm{G}_{\mathrm{H} 2}$ values for these materials were 0.015 molecules $/ 100 \mathrm{eV}$ and 0.037 molecules $/ 100 \mathrm{eV}$ for $\mathrm{w} / \mathrm{c}$ ratios of 0.2 and 0.3 , respectively. The observed $\mathrm{G}_{\mathrm{H} 2}$ values are in good agreement with $\mathrm{G}_{\mathrm{H} 2}$ values calculated from data reported by Bibler ${ }^{3}$ for radioactive concrete waste forms, and they are about a factor of two or more below the estimated $\mathrm{G}_{\mathrm{H} 2}$ of 0.072 needed to achieve an americium waste loading of about $28 \mathrm{~W}$ per SWB.

Initial expectations that hydrogen generation rates could be estimated from pressure changes alone were confounded by simultaneous removal of oxygen as evidenced by the non-radioactive control samples. The fact that an increase in the nitrogen-to-oxygen ratio was observed for the control samples but not for the radioactive samples suggests that radiolytic oxygen as well as hydrogen is being produced.

The results of this scoping study suggest that it is feasible to reduce the $\mathrm{G}_{\mathrm{H} 2}$ of radioactive concrete waste forms to an acceptable value by limiting the w/c ratio in the waste/cement mixture. However, the scoping test data are insufficient to state this conclusion with high confidence given the limited number of replicates and short duration of these tests. Additional gas generation tests with waste forms containing americium-241 and all of the other constituents of the MOX high alpha waste stream (including RCRA metals and organic additives) are needed to confirm these results. Additional experiments are also needed to establish the reproducibility of the observed hydrogen generation rates and variability due to differences in release rates of hydrogen from the waste forms. The release rates and gas generation rates will vary with waste form composition and any additives used. Future tests will address the normal variation in waste form composition. These additional qualification tests will be necessary to gain Nuclear Regulatory Commission approval for shipment of the high-activity concrete waste form to the WIPP. 
WSRC-TR-2003-00350

Revision 0

\subsection{References}

1. TRUPACT-II Authorized Methods for Payload Control (TRAMPAC), Revision 19a, March 2002; Westinghouse TRU Solutions, LLC; Carlsbad, NM.

2. An Introduction to Radiation Chemistry; J. W. T. Spinks and R. J. Woods; John Wiley \& Sons, New York, 1964, p. 3.

3. N. E. Bibler, "Radiolytic Gas Generation in Concrete Made with Incinerator Ash Containing Transuranium Nuclides," in Scientific Basis for Nuclear Waste Management, Vol. 2 (1980); C. J. M. Northrup, Jr., Ed.; Plenum Publishing, New York; pp 585 - 592.

4. C. O. Jones, "Hydrogen Generation Scoping Study for Waste Forms Produced from the WSB," Technical Task Request NMMD-2003-197, 2/13/2003.

5. X-CLC-F-00391, "Flow Sheet Calculation for the Waste Solidification Building," C. Jones, 5/13/03.

6. TRUPACT-II Authorized Methods for Payload Control (TRAMPAC), Revision 19a, March 2002, p. 5.5-6; Westinghouse TRU Solutions, LLC; Carlsbad, NM.

7. ASTM Standard C 150-02a, "Standard Specification for Portland Cement," October 2002.

8. Personal communication from Christine Langton and Alex Cozzi, Waste Processing Technology Section, Savannah River Technology Center, August 2003. 